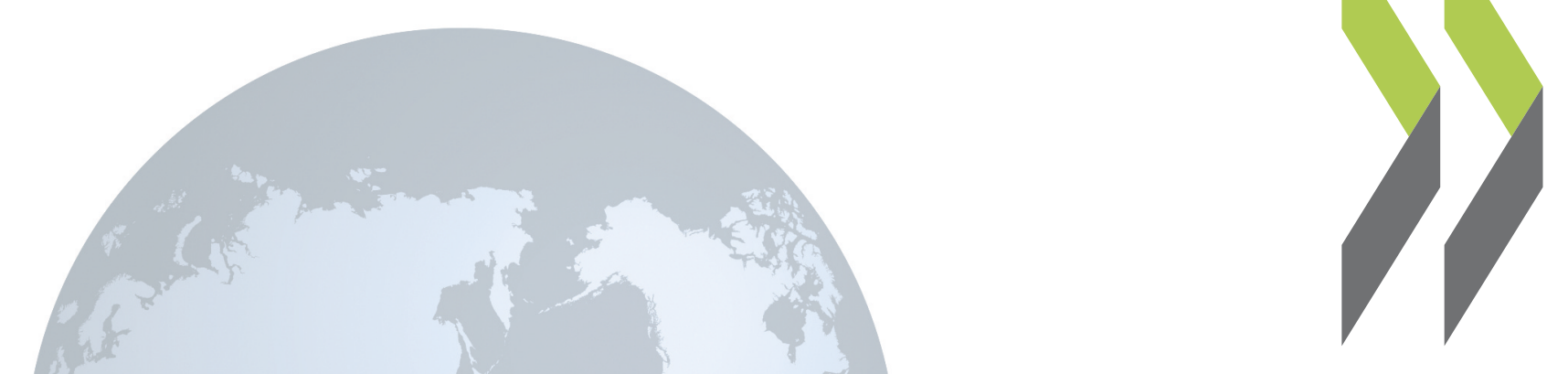

OECD Regional Development Working Papers 2012/05

\title{
Measuring the Environmental Performance of Metropolitan Areas with Geographic Information Sources
}

Mario Piacentini, Konstantin Rosina 


\section{OECD REGIONAL DEVELOPMENT WORKING PAPERS}

This series is designed to make available to a wider readership selected studies on regional development issues prepared for use within the OECD. Authorship is usually collective, but principal authors are named.

The papers are generally available only in their original language English or French with a summary in the other if available.

The opinions expressed in these papers are the sole responsibility of the author(s) and do not necessarily reflect those of the OECD or the governments of its member countries.

Comment on the series is welcome, and should be sent to either gov.contact@oecd.org or the Public Governance and Territorial Development Directorate, 2, rue André Pascal, 75775 PARIS CEDEX 16, France.

OECD Regional Development Working Papers are published on www.oecd.org/gov/regional/workingpapers

Applications for permission to reproduce or translate all or part of this material should be made to: OECD Publishing, rights@oecd.org or by fax 33145249930.

(C) OECD 2012 


\title{
MEASURING THE ENVIRONMENTAL PERFORMANCE OF METROPOLITAN AREAS WITH GEOGRAPHIC INFORMATION SOURCES
}

\begin{abstract}
This paper presents recent work undertaken at the OECD to produce environmental indicators at the regional level from geographic data sources. New indicators have been tested and produced in five different domains: a) land cover, b) forest ecosystems, c) urban density, d) $\mathrm{CO} 2$ emissions, e) air quality. The indicators measure the environmental performance of administrative regions (OECD TL2 and TL3 regions) and of OECD metropolitan areas. High-quality geographic datasets have been combined and harmonized with the objectives of producing internationally comparable results, and of achieving the largest possible coverage of OECD and non-OECD countries. The results show that geographic information data are a key and underexploited resource for monitoring the state of local environmental assets. There are still methodological and measurement challenges in the use of geographic data for the analysis of environmental changes at the local level. More coordination across national and international programs producing geographic data is needed to further increase their policy relevance.
\end{abstract}

Keywords: Geographic Information Systems, Environment, Regional Development

JEL: Q5, R1

\section{Acknowledgement}

The paper has been written by Mario Piacentini (OECD), and by Konstantin Rosina (Institute of Geography, Slovak Academy of Sciences and OECD). The authors thank Monica Brezzi, the Delegates of the OECD Working Party on Territorial Indicators and the Delegates of the OECD Working Group on Environmental Information and Outlooks for valuable comments on earlier versions. Questions and comments should be addressed to Mario Piacentini: mario.piacentini@oecd.org 


\section{Integrating spatial and socio-economic data for regional analysis}

Regional development is a multi-dimensional process that can be adequately understood only through the integration of different data and measures. This integration of information is essential given the interdependencies linking economic, social and environmental changes at the local level. In particular, sustainable regional development requires integrated policies pursuing simultaneously economic growth, social cohesion and environmental protection.

The development of statistics on the state and changes of local environmental assets is a challenging task. While countries have started to invest more resources in the monitoring of key environmental variables, such as carbon emissions, data are rarely collected and analyzed at the sub-national level. This is problematic given that national averages hide great geographic differences in contributions to natural resource depletions and exposure to environmental risks.

This paper illustrates recent advancements in: $i$ ) the development of methodologies to derive environmental indicators from geographic sources in different domains; ii) the production of these indicators at different geographic levels (regions, metropolitan areas); iii) the inclusion of these indicators in the OECD Regional Database and Metropolitan Areas Database. These indicators from geographic sources can be examined together with more established indicators of regional performance, such as GDP, population growth and characteristics of local industries. Such an analysis is expected to provide new information on how human activity and the living environment co-evolve and interact.

The selection of the indicators has been mainly based on the relevance of the environmental issue they shed light on. Relevance is defined on the basis of the costs of inaction or, equivalently, on the basis of the potential benefits from policy action in the area. Within this conceptual framework, costs and benefits are evaluated both in terms of current life quality and environmental performance, both in terms of sustainability of our living and resource-use system. The indicators described in this paper do not mean to provide an exhaustive set of information on the state and performance of urban and regional environment. They need to be complemented by additional indicators that are generally available from non-geographic sources, such as those referring to waste management, urban transport and energy generation and use.

The following 13 environmental indicators have been selected in five domains and estimated for different geographic units of analysis.

Table 1. Environmental indicators developed for regions and metropolitan areas

\begin{tabular}{|c|c|c|}
\hline Domains & Indicators & $\begin{array}{c}\text { Geographic unit of } \\
\text { analysis }\end{array}$ \\
\hline \multirow{6}{*}{ Land cover and land cover changes } & Percentage of area covered by urbanised land & TL2; TL3, metro \\
\hline & Percentage of area covered by agricultural land & TL2; TL3, metro \\
\hline & Percentage of area covered by forested land & TL2; TL3, metro \\
\hline & Growth of urbanised land; & TL3, metro \\
\hline & Growth of agricultural land & TL3, metro \\
\hline & Growth of forested land & TL3, metro \\
\hline Forest ecosystem and carbon absorption & Net primary productivity of regional vegetation & TL2 \\
\hline \multirow{2}{*}{ Urban density } & High density development index & Metro \\
\hline & Densification index & Metro \\
\hline \multirow{2}{*}{ CO2 emissions } & CO2 emissions per capita & TL2; metro \\
\hline & CO2 efficiency of production & TL2; metro \\
\hline \multirow{2}{*}{ Air quality } & Average population exposure to PM2.5 & TL2; metro \\
\hline & $\begin{array}{l}\text { Percentage of population exposed to health damaging } \\
\text { PM2.5 }\end{array}$ & TL2; metro \\
\hline
\end{tabular}


The indicators presented in this paper are of two types. The first set of indicators are based on remotely sensed source data at different levels of resolution, and obtained through overlay analysis e.g. the statistics for one region are obtained by superimposing the source data layer with the layer of regional boundaries. In these cases, the regional value is either the sum or a weighted average of the values observed in the source data within the (approximated) area delimited by the regional boundaries. Examples of this first type of indicator are the measures of urban surfaces, obtained by moderate resolution satellite data at a global scale from the MODIS satellite sensor. The second set of indicators are obtained through data that are available at the national level, but have been downscaled to regularly spaced "grids" (e.g. $1 \mathrm{~km}$ by $1 \mathrm{~km}$ squares) using additional data inputs that capture how the phenomenon of interest is distributed across space. Examples of this second type of statistics are the regional estimates of $\mathrm{CO}_{2}$ emissions from EDGAR gridded data. These estimates have been obtained by downscaling national data on emissions level to regularly spaced grids, through a model that uses information on observable elements that are correlated with the production of emissions, such as population density, roads and factories.

One of the main advantages of using data from satellite observations is that they enable a high level of comparability of the results for regions in different countries. This comparability across space is generally higher than the one achievable through measurement based on in-situ monitoring stations, which are unevenly distributed over space and still not available in less advanced countries. The comparability across time of the measures can become problematic as new tools and new models continue to improve the measurement quality of the new data points with respect to the older data points. Specific data products enabling comparison of data over time need to be produced, and these products often require considerable investments. There are still few international standards for the production of indicators from remote sensing observation. Moreover, there is a lack of coordination across the established international programs, so that we often observe inefficient duplications.

The indicators presented in this paper provide relevant comparisons of the state of the environment at the local level. They also give policy insights on key dynamics occurring at different paces in different areas, such as the expansion of urban settlements. The indicators will enrich both the OECD Regional Database and the new OECD Metropolitan Area Database (OECD 2011c).

This paper is organised as follows: For each of the five domains we present $i$ ) the policy rationale for the development of the indicators, ii) the selected indicators, iii) some selected results, and $i v$ ) the standing issues in terms of measurement and update of results. The paper concludes with a discussion of the possibilities for further data development to monitor the environmental and socio-economic indicators for regions and metropolitan areas. The data sources and the data processing are described in detail in the Annex, so that interested researchers can replicate the results.

\section{Land cover and its changes}

\section{Policy rationale for the development of the indicators}

On a global basis, nearly 6.8 million $\mathrm{km}^{2}$ of forest, woodlands and grasslands have been converted to other land uses in the last three centuries (Agarwal et al. 2002) and most of the changes were into urban land use. Land cover changes represent a pressing environmental issue, and are both a cause and a consequence of climate change (Herold 2009). There is increasing evidence that the type and distribution of land cover also impact regional weather and climate patterns. Rapid phenomena of land cover change not only affect ecosystems and landscapes, but can more generally lead to an increased vulnerability of both human and environmental systems.

While land cover and land use are often used interchangeably, in reality they represent quite different concepts. Land cover refers to the observed physical cover of the Earth's surface, while land use requires 
socio-economic interpretation of the activities that take place on that surface (Fisher et al. 2005). Land cover and land use are linked through complex many-to-many relationships. Grass, for example, is a type of land cover which corresponds to several types of land uses: sports grounds, urban parks, residential land, pasture, etc. At the same time, very few areas of homogenous land use have a single land cover. Residential land, for example, may contain trees, grass, buildings and asphalt (Fisher et al. 2005). While land use is the most relevant phenomenon for policy and planning purposes, the indicators presented in this section are based on land cover data ${ }^{1}$. This is motivated by reasons of data availability. Medium resolution satellite imagery does not allow direct and reliable inference of land uses, while it enables to record the extent of distinct land cover types on the basis of spectral radiance. ${ }^{2}$

\section{Selected indicators and their derivation}

Work has been undertaken to develop static and dynamic regional indicators of land cover. The static indicators have a global coverage. They have been developed for OECD member and enhanced engagement countries (Brazil, China, India, Russia and South Africa), but can be extended to TL2 regions in any country. The dynamic indicators are for the moment only available for European countries, United States and Japan, given the current lack of land cover change data for other countries.

The static indicators are:

- Percentage of area covered by urbanised land

- Percentage of area covered by agricultural land

- Percentage of area covered by forested land

The dynamic indicators are:

- Growth of urbanised land

- Growth of agricultural land

- Growth of forested land

The growth rates are calculated in net terms: for example, the rate of change of urban area is calculated as the amount of land converted to urban land cover minus the urban land converted to other classes, as a fraction of the urban land in the starting year.

It was possible to develop the indicators only after the definition of an appropriate methodology to improve the comparability of the land cover datasets for United States, Japan, and European countries. This work of harmonisation is described in detail in Table 7 of the annex.

1. One exception are the data used for Japan, that are closer to the land use concept.

2. There is a growing international commitment to record land use and land cover through various land classification programmes. A limited number of these programs have been explicitly designed to monitor changes. These programmes include the US National Land Cover Dataset, the Countryside Survey series in the UK, the European CORINE Land Cover mapping, the International Land Use and Land Cover Change core project and the International Human Dimensions Programme on Global Environmental Change. Connected to these data collection efforts, there is a very active research agenda producing sophisticated models of determinants and consequences of land cover changes. This research predicts significant effects of land-use and land-cover change on Earth's surface albedo (re-flectance), snow cover, and the carbon cycle. 


\section{Selected results}

Table 2 shows results for the dynamic indicator on the net growth of urban land in the largest metropolitan area of each country with available land cover change data. Distinct indicators have been produced for the metro cores and for the hinterlands. As expected, we observe in general a much more marked increase in urban land in the hinterlands of OECD metropolitan areas. These land conversions have been particularly intense in Ireland, Portugal, Spain and Estonia.

Table 2. Growth of urban land in cores and hinterlands, largest metropolitan area in each country (2000-06)

\begin{tabular}{|l|l|c|c|c|}
\hline Country & Metropolitan area & $\begin{array}{c}\text { Urban net change } \\
\text { rate (core) }\end{array}$ & $\begin{array}{c}\text { Urban net change } \\
\text { rate (hinterland) }\end{array}$ & $\begin{array}{c}\text { Urban net change } \\
\text { rate (overall) }\end{array}$ \\
\hline Austria & Wien & $0.41 \%$ & $1.67 \%$ & $1.36 \%$ \\
\hline Belgium & Brussel & $0.00 \%$ & $0.23 \%$ & $0.19 \%$ \\
\hline Czech Republic & Praha & $1.33 \%$ & $3.92 \%$ & $2.71 \%$ \\
\hline Denmark & København & $2.45 \%$ & $4.98 \%$ & $3.88 \%$ \\
\hline Estonia & Tallin & $2.61 \%$ & $13.61 \%$ & $8.99 \%$ \\
\hline Finland & Helsinki & $1.91 \%$ & $3.60 \%$ & $2.70 \%$ \\
\hline France & Paris & $0.74 \%$ & $2.83 \%$ & $0.37 \%$ \\
\hline Germany & Berlin & $0.00 \%$ & $1.64 \%$ & $2.44 \%$ \\
\hline Hungary & Budapest & $1.55 \%$ & $3.31 \%$ & $15.67 \%$ \\
\hline Ireland & Dublin & $6.25 \%$ & $33.51 \%$ & $2.87 \%$ \\
\hline Italy & Milano & $2.06 \%$ & $4.79 \%$ & $5.64 \%$ \\
\hline Japan & Tokyo & $4.93 \%$ & $9.30 \%$ & $6.39 \%$ \\
\hline Netherlands & Amsterdam & $6.56 \%$ & $4.55 \%$ & $0.73 \%$ \\
\hline Norway & Oslo & $0.22 \%$ & $0.89 \%$ & $1.91 \%$ \\
\hline Poland & Warsaw & $1.90 \%$ & $1.96 \%$ & $9.57 \%$ \\
\hline Portugal & Lisboa & $5.73 \%$ & $21.15 \%$ & $1.16 \%$ \\
\hline Slovak Republic & Bratislava & $0.81 \%$ & $1.32 \%$ & $0.64 \%$ \\
\hline Slovenia & Ljubljana & $0.61 \%$ & $0.65 \%$ & $14.57 \%$ \\
\hline Spain & Madrid & $17.17 \%$ & $13.89 \%$ & $1.69 \%$ \\
\hline Sweden & Stockholm & $0.84 \%$ & $2.15 \%$ & $0.33 \%$ \\
\hline Switzerland & Zürich & $0.72 \%$ & $0.11 \%$ & $0.32 \%$ \\
\hline United Kingdom & London & $0.17 \%$ & $0.76 \%$ & $1.68 \%$ \\
\hline United States & New York & $0.56 \%$ & $3.50 \%$ & \\
\hline
\end{tabular}

\section{Remaining issues for measurement and updates}

There is scope for further research of methods that could correct for some of the discrepancies across the different datasets, e.g. in the minimum mapping unit. To clarify, while in EU countries Corine Land Cover (CLC) allows only for identification of changes larger than 5 hectares (which can be considered insufficient for urban growth monitoring), the National land Cover Dataset (NLCD) in the United States is able to capture also much less marked changes. To improve comparability, changes that are smaller than those recorded in CLC could be dropped, but at the cost of information loss.

The Japan National Land Information Service (JNLIS) datasets have been released already five times since 1970s. Both CLC and NLCD have been released already for three time horizons and can be considered as successful projects. Bearing in mind the growing concern about monitoring of environmental changes, we can expect a continuation of these projects. 


\section{The state of forest ecosystems and carbon absorption}

\section{Policy rationale for the development of the indicators}

Monitoring the healthiness or "productivity" of forest ecosystems is essential, as forests play a large role in the world's carbon budget, absorbing carbon dioxide $\left(\mathrm{CO}_{2}\right)$ in the process of photosynthesis. Every year, forest photosynthesis absorbs approximately one-twelfth of the atmospheric stock of carbon dioxide (Malhi et al, 2002). The land cover indicator on change in forested areas provides relevant information on the pressure put on forested land by human activity and by changes in climate and atmospheric composition. It is important to complement this indicator with information on the state of natural vegetation. This information is provided by a new indicator measuring "Net Primary Productivity (NPP)" of a region's vegetation. NPP measures how much carbon dioxide vegetation takes in during photosynthesis minus how much carbon dioxide the plants release during respiration or decay. NPP is a fundamental ecological variable, for its capacity to measure the energy input to the biosphere and terrestrial carbon dioxide assimilation, and also because of its significance in indicating the condition of a wide range of ecological processes.

Vegetative productivity is the source of all food, fiber and fuel available for human consumption and therefore defines the habitability of the earth. Recent research has shown that a severe threat to environmental sustainability can arise from an imbalance of demand for food, fiber, wood, and increasingly biofuels with respect to supply of forest primary production. ${ }^{3}$ Imhoff et al. (2006) use consumption data from the UN Food and Agriculture Organisation to calculate the annual amount of NPP required for the products consumed. Their results show that NPP demand as percent of supply has been increasing and is likely to increase substantially in the next 40 years as a result of population growth, rising demand for biofuels, and land conversion for agriculture and urbanisation purposes, despite better harvesting and processing efficiencies. Related research has shown that most of the new urbanisation in the United States has taken place on the lands with relatively high rates of NPP. Humans exert an additional influence on global NPP through fires. Human influence over the capacity of the Earth to generate products of photosynthesis has been shown to change the composition of the atmosphere, to impact important ecosystem services such as fresh water availability, and to threaten biodiversity.

These findings have evident implications for land management policy. They show how 'local' decisions are 'strictly' related to a global issue such as climate change. Improvements in our understanding of forest carbon dynamics can lead to better policy decisions related to forest production or conservation. Any activity affecting the amount of biomass in vegetation and soil has the potential to sequester carbon from, or release carbon into, the atmosphere. Recognising this simple principle, programmes for carbon capture, storage and sequestration have started to be implemented at the national and local scale. For example, the US Department of Energy has created a network of seven Regional Carbon Sequestration Partnerships (RCSPs) to help develop the technology, infrastructure, and regulations to implement largescale $\mathrm{CO}_{2}$ sequestration in different regions and geologic formations. These programs, if upscaled, have the potential to make significant contributions to controlling the rise in $\mathrm{CO}_{2}$ emissions in the next few decades.

\section{Selected indicator and its derivation}

The selected indicator on the state of forest is the following:

- Net primary productivity (NPP) measured as grams of carbon per square meters.

3. The net primary production of a forest consists of the accumulation of stem wood in standing trees plus the growth of all the other tissues or components including those that are short lived. 
The rate at which light energy is converted to plant biomass is termed primary productivity. The sum total of the converted energy is called gross primary productivity (GPP). The net primary productivity (NPP) indicator is the difference between GPP and energy lost during plant respiration (Campbell 1990). The indicator provides local-level information on forest productivity and on the contribution of natural vegetations to carbon absorption. It has been developed for OECD TL2 regions.

\section{Selected results}

Figure 1 shows the range in average regional values of NPP. They can be interpreted as the contribution of a region's vegetation to carbon sequestration from the atmosphere (e.g. highly urbanised regions are expected to have low values, agricultural regions medium values and forested regions high values of the indicator).

Figure 1. Regional Range in NPP (2000-06)

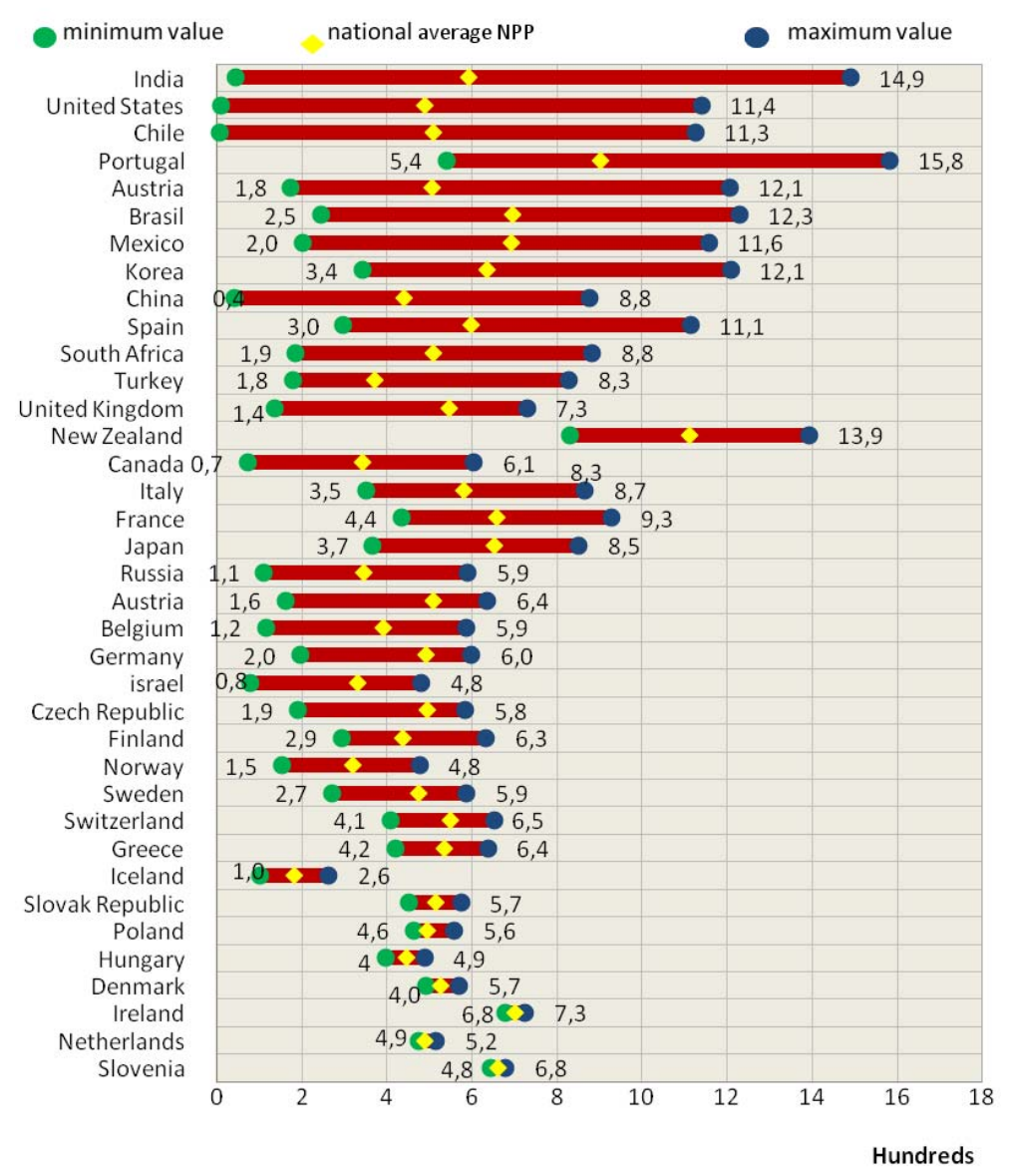

Source: OECD (2011), OECD Regions at a Glance 2011, OECD Publishing, Paris.

As evident from Figure 1, there are very large differences within countries in carbon absorption through plant biomass production. In India, United States and Chile, for example, we can observe regions with very high and with very low levels of NPP. The allocation of specific resources to protect the important carbon reserves existing in virtually all countries is justified not only in terms of landscape preservation and biodiversity, but also for the global objective of climate change mitigation. 


\section{Remaining issues for measurement and updates}

One of the main issues is the complexity of the models providing the NPP estimates used as inputs for the local and regional indicators. This complexity makes particularly hard to conclude to what extent estimated trends, or rate of changes, are linked to real natural changes or derive from the particular design of the models' algorithms. In terms of data reliability, remotely sensed data collected from space provide coarser assessments of NPP and GPP than inventory and meteorological tower based methods, but have the advantage of providing estimates of terrestrial primary production for large areas where ground-based methods are not feasible (Gough, 2011).

The multiplicity of the factors that can influence NPP makes also difficult to infer to what extent observed trends at the local level can be associated to particular events, such as droughts induced by global warming or conversion of forested lands. Data updates for the years after 2006 are expected to be published in early 2012 .

\section{Indicators of urban density}

\section{Policy rationale for the development of the indicators}

Indicators of urban density can provide relevant information on the impact of the "form" of urbanisation on the environment. There is in fact increasing empirical evidence that the densification of cities lowers their carbon footprints (OECD, 2010). Given the complexities of raising density in the inner cities, many of the policy initiatives for "compact cities" target the urban fringes and the hinterlands, with the objective of deterring the phenomenon of 'urban sprawl'. Urban sprawl has been defined as a specific form of urban development with low-density, dispersed, auto-dependent and environmentally and sociallyimpacting characteristics (Ewing, 1997). The definition and measurement of sprawl is still controversial. It has been thus chosen to focus on the development of simple measures of urban density and of efficiency of urban development.

\section{Selected indicators and their derivation}

The functional metropolitan areas defined for the new OECD Metropolitan Areas Database are the relevant geographic unit for the indicators on urban density (OECD $2011 \mathrm{c})$. Two indicators have been selected to describe the distribution of population in metropolitan areas and the efficiency of new urban development (new land resource used in relation to number of people supported):

- High density development index.

- Densification index.

The high density development index is inspired by the work of Lopez and Hynes (2003) assessing the levels of sprawled urban development across US metropolitan areas. The indicator measures the proportion of people in the hinterland and in the metro core living in highly densely populated $1 \mathrm{sq} \mathrm{km}$ grid cells. This high density development index is obtained using as a threshold the median density of the metro area, as defined from the population grid data. In order to exclude outliers (e.g. cells with zero inhabitants) we exclude from the computation the lowest and highest density cells (the $5 \%$ of the cells at the two extremes of the density distribution).

The densification index is mainly meant to capture the level of critical land resources lost in relation to human population growth. The indicator is defined as the ratio between the population increase (in metro, core and hinterland), with respect to the increase in "urbanised land", i.e. the surface that is categorised as urban. This ratio is increasing with a more compact residential development - e.g. when a given increase in the developed land hosts a relatively high number of people. 


\section{Selected results}

Table 3 presents the results from the derivation of the high density development index for the selected cities of Paris, Milan and Barcelona. The index shows clearly the differences in the distribution of densities between the cores of the metropolitan areas and their hinterlands. Almost the totality of the population of the urban cores of Paris and Barcelona live in high-density residential units, while $10 \%$ of the population in Milan's core lives in relatively low-dense areas.

Table 3. High density development index

\begin{tabular}{|l|c|c|}
\hline \multirow{3}{*}{ Maris } & Petropolitan area & High density development index \\
& Total & 88.75 \\
\cline { 2 - 3 } & Core & 98.88 \\
\cline { 2 - 3 } & Hinterland & 45.20 \\
\hline \multirow{3}{*}{ Milan } & Total & 79.38 \\
\cline { 2 - 3 } & Core & 89.66 \\
\cline { 2 - 3 } & Hinterland & 54.00 \\
\cline { 2 - 3 } & Total & 93.06 \\
\cline { 2 - 3 } & Core & 99.20 \\
\cline { 2 - 3 } & Hinterland & 50.34 \\
\hline
\end{tabular}

Note: The high density development index is inspired by the Lopez-Hynes indicator of urban sprawl, and it tells the proportion of people living in highly densely inhabited residential units (1 sq km grids) within the metropolitan area.

Table 4 presents results from the computation of the densification index in the same three metropolitan areas. We can observe that the efficiency of urban development as measured by the densification index over the period from 1990 to 2006 has been the highest in Paris, mainly due to a large increase of the population in its metro core.

Table 4. Densification index

\begin{tabular}{|l|l|c|c|c|}
\hline & \multicolumn{1}{|c|}{$1990-2006$} & & & \\
\hline & & New Urban (ha) & Pop change & Densification index \\
\hline Milan & Metro area & 4504 & 264057 & 58.63 \\
\hline & Core & 1739 & 55253 & 31.77 \\
\hline Barcelona & Hinterland & 2765 & 208804 & 75.52 \\
\hline & Metro area & 8602 & 560000 & 65.1 \\
\hline Paris & Core & 5347 & 258308 & 48.31 \\
\hline & Hinterland & 3255 & 301692 & 92.69 \\
\hline & Metro area & 12495 & 966698 & 77.37 \\
\hline
\end{tabular}

Note: The densification index is given by the ratio between the population change and the change in hectares covered by urban surfaces. OECD computation based on National Statistics Population data and Corine Land Cover data (EEA).

\section{Remaining issues for measurement and updates}

The high density development index gives an illustration of the concentration of people in space (an outcome inconsistent with sprawled development). A limitation of the index is that it does not take into account the location of the high-density parcels over the urban space, and thus provides only a partial description of the form of urban development. Consider, as an example, the case of two metro areas. One has a high concentration of people in the central business district, with density decaying uniformly as one departs from the center. The second has a polycentric structure with several residential and commercial nodes hosting relevant concentrations of population. These two metros have a very different urban form, but can have the same value of the high-density index. Moreover, one contentious issue is the choice of thresholds for the index. In its proposed form, the index uses as thresholds the median value for each 
metropolitan area. For international comparisons, it might also be interesting to fix a unique threshold for all the metropolitan areas, even if it is not straightforward to define the value of such a threshold.

The high density development index is based on population grid data, normally available only for the Census years. The future availability of statistics for 2010 from the new census round will make it possible to obtain updated gridded population data, so that values for the index can be compared over a decade.

Regarding the densification index, the interpretation of the results will be simplified through an adequate normalisation of the range of possible values. In fact, one issue is that the index gets a negative value when either the growth of the population or of the growth of urban land are below zero. In presence of negative values, it is not possible to disentangle which of the two phenomena - depopulation or decrease in built-up areas - drives the result. The issue is particularly problematic in the cases of areas experiencing over the same period negative population growth and negative built-up area growth. A possible solution is to use the maximum and minimum values across all the OECD metropolitan areas for the normalisation, and restrict the measurement to the metro areas with strictly positive population and urban land changes.

\section{Estimates of $\mathrm{CO}_{2}$ emissions at the regional and urban level}

\section{Policy rationale for the development of the indicators}

Greenhouse gas carbon dioxide $\left(\mathrm{CO}_{2}\right)$ from the combustion of fossil fuels and from biomass is a major contributor to greenhouse gas $(\mathrm{GHG})$ emissions and to the enhanced greenhouse effect. Accounting for over $80 \%$ of total GHG emissions, $\mathrm{CO}_{2}$ is a key factor in countries' ability to deal with climate change. The levels of atmospheric concentrations of $\mathrm{CO}_{2}$ continue to increase worldwide due to anthropogenic activities, having roughly doubled since the early 1970s (OECD 2011 b). Given the increasing urbanisation and industrialisation in emerging and developing countries, there are projections of further increases in $\mathrm{CO}_{2}$ concentrations over the next decades, unless strong national and international strategies are put in place to decouple $\mathrm{CO}_{2}$ and other GHG emissions from economic growth. There is increasing understanding that urban and regional policies (e.g. compact-city policies) can complement global climate policies (e.g. a carbon tax) by reducing global energy demand and $\mathrm{CO}_{2}$ emissions.

Continued efforts are being done to further improve national GHG inventories, and in particular to better take into account international flows of carbon associated to the increasing interdependencies of international production networks and supply chains. An accurate knowledge of the spatial and distribution of surface emissions and of their evolution is essential to address air quality and climate change issues (Granier et al., 2010). Over the last years, more attention has been devoted to the measurement of cities' carbon emissions. One example is the attempt by 500 cities members of ICLEI (International Coalition for Local Environmental Initiatives, now known as Local Governments for Sustainability) to establish baseline measurement of emission levels on the basis of a common methodology. Still, the prevailing model followed by large cities in OECD is to develop their own estimates of $\mathrm{CO}_{2}$ emissions, with their own model and assumptions. These individual initiatives are justified by the persisting absence of a global protocol for quantifying GHG emissions attributable to urban areas. However, they strongly limit the comparability of the available figures. In the current debate over the development of such a protocol, the focus of the discussions has been on two main issues: a) consumer versus producer approach to measurement, ${ }^{4}$ b) treatment of the significant cross-boundary energy flows (i.e. emission of airline travels from a city's airport).

4. A consumer approach is one where the emissions from the production of a good or service are allocated to the consumer of that good or service, no matter where production takes place. A 'producer' approach is one where the emissions associated with an activity are allocated to where that activity takes place (Kennedy et al 2009). 
It is surprising that this debate has almost ignored the key issue of the comparability of the way cities are defined across countries. In fact, consistent comparisons of absolute and per capita carbon emissions in cities require, as a pre-condition, that the boundaries of cities are defined in a consistent way. There are in fact large discontinuities in the level and carbon intensity of economic activities within cities, so that it is problematic to compare baseline estimates that have been developed for cities defined according the administrative criteria (where the relevant area is often restricted to the historical urban core) with those developed for functional metropolitan areas (where the relevant area includes the less populated areas that are part of the urban labor market).

In this section, we present an attempt to build estimates for cities and for regions on the basis of spatially disaggregated national emission data. The city-level estimates have the notable advantage of being developed for urban areas defined according to a common methodology (the newly defined OECD metropolitan areas).

\section{Selected indicators and their derivation}

The following two indicators have been selected to describe the overall level of $\mathrm{CO}_{2}$ emissions in regions and metropolitan areas, and the relative decoupling between domestic production and carbon inputs:

- $\mathrm{CO}_{2}$ emissions per capita

- $\mathrm{CO}_{2}$ efficiency of production

The first indicator has been produced aggregating all the measured sources of $\mathrm{CO}_{2}$ emissions, with the exception of international aviation and navigation. $\mathrm{CO}_{2}$ efficiency of production is defined as the ratio between GDP and $\mathrm{CO}_{2}$ values. This second indicator provides information about the carbon intensity of economic activity in cities and regions with a focus on the production side. A complementary indicator under consideration uses income instead of GDP in the calculation of the ratio, so to inform about the relative decoupling of demand-based emissions from income.

\section{Selected results}

Table 5. Estimates of $\mathrm{CO}_{2}$ emissions (2005) - ten largest OECD metropolitan areas

\begin{tabular}{|c|c|c|r|r|c|}
\hline Rank & Country & Metropolitan area & $\begin{array}{c}\text { CO2 emissions } \\
\text { per capita [tons] }\end{array}$ & $\begin{array}{c}\text { Share in country's } \\
\text { total emission }\end{array}$ & $\begin{array}{c}\text { Share in country's } \\
\text { total population }\end{array}$ \\
\hline 1 & Japan & Tokyo & 7.81 & $22.47 \%$ & $25.75 \%$ \\
\hline 2 & Korea & Seoul - Incheon & 5.87 & $26.11 \%$ & $42.69 \%$ \\
\hline 3 & Mexico & Mexico City & 3.42 & $12.59 \%$ & $17.47 \%$ \\
\hline 4 & Japan & Osaka & 7.66 & $11.50 \%$ & $13.44 \%$ \\
\hline 5 & United States & New York & 17.44 & $4.77 \%$ & $5.72 \%$ \\
\hline 6 & United States & Los Angeles & 14.50 & $3.85 \%$ & $5.56 \%$ \\
\hline 7 & France & Paris & 7.45 & $18.19 \%$ & $18.38 \%$ \\
\hline 8 & United Kingdom & London & 17.92 & $2.73 \%$ & $18.02 \%$ \\
\hline 9 & United States & Chicago & 14.39 & $1.59 \%$ & $3.18 \%$ \\
\hline 10 & United States & San Francisco & & $2.31 \%$ \\
\hline
\end{tabular}


Table 5 shows the result from the allocation of EDGAR gridded values to the ten largest OECD metropolitan areas. These large metropolitan areas concentrate a sizable fraction of their countries' total emissions. The estimates show sizable differences in the levels of total $\mathrm{CO}_{2}$ per capita across these major cities. In several cases, it is possible to observe significant differences between the share of country's population living in a metropolitan area and the contribution of the area to the country's total emissions.

Figure 2. $\mathrm{CO}_{2}$ Efficiency of production, TL2 regions with highest value and country average, 2005

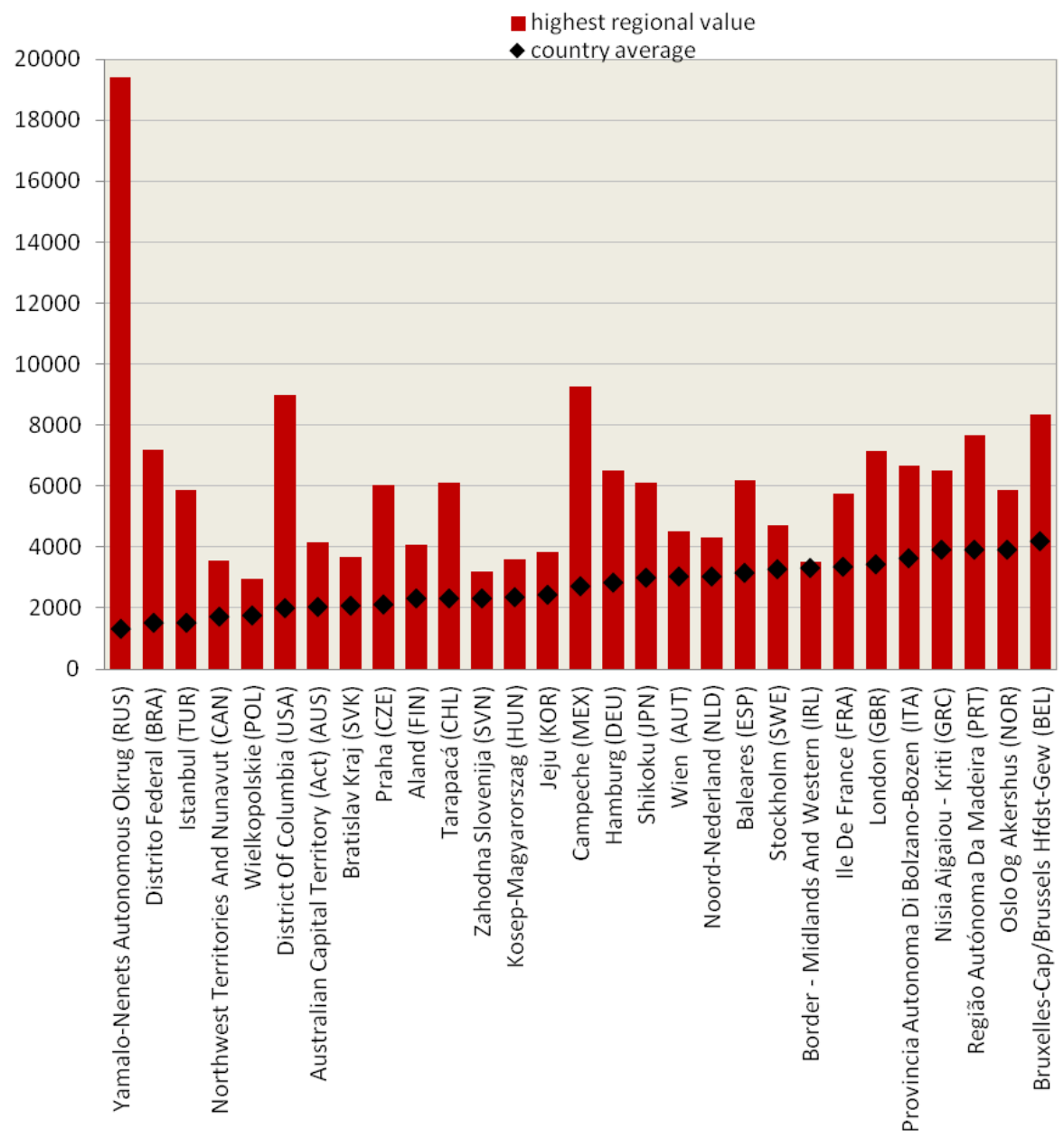

Source: OECD (2011), OECD Regions at a Glance 2011, OECD Publishing.

Figure 2 shows the large differences in the carbon efficiency of production that exist within countries. Particularly in Turkey, in the United States, in Brazil and in the Russian Federation, some regions show much higher carbon efficiency than the national average.

\section{Remaining issues for measurement and updates}

The indicators presented above are useful as they allow a first comparative assessment of the challenges faced by different cities toward the goal of sustainable levels of $\mathrm{CO}_{2}$ emissions. With respect to available data, they have the advantages of being defined on the basis of a common methodology and being applied to urban areas defined in a comparable way. However, since they are based on national 
values downscaled to the local levels, rather than on actual measurement at the local level, the estimates should be used with caution, keeping in mind they represent approximate figures.

The main limitation of the $\mathrm{CO}_{2}$ indicators is the fact that the source data are disaggregated on the basis of a model and hence provide only approximation of the "real" emission values. The accuracy of the spatial allocation model depends largely on the selection and quality of ancillary data. Another drawback is that the accuracy of the downscaled measures might vary across places as a result of uneven availability and accuracy of the ancillary spatial data used for disaggregation.

For what regards the temporal comparison of the figures, more analysis is required to assess whether the observed change over time in the data reflect indeed changes in local $\mathrm{CO}_{2}$ concentrations or are due to the spatial distribution methodology. In particular, it still has to be verified whether the ancillary data remain the same from 2000 to 2005 or are constantly updated.

\section{Air quality}

\section{Policy rationale for the development of the indicators}

Ground-level ozone, fine particulates and toxic air pollutants raise growing concerns for their effects on health, in particular for urban dwellers. The increasing use of private vehicles for commuting in urban areas of emerging economies is greatly raising the number of people that are exposed to toxic pollutants. Urban air pollution is estimated to cause about 2 million premature deaths (a loss of 6.4 million years of life) each year (OECD, 2010). Effects of this size have obvious consequences on health expenditures and on economic activity. The measurable public health benefits from the Clean Air Act in 2010 are estimated to prevent 13 millions of lost work days and to amount to savings for USD 2 trillion, outweighing related costs by a factor of 30 to 1 (OECD, 2011b).

Health-damaging air pollution is often measured by the concentration of particulate matters (PM) in the air. Particulate matters (PM) consist of small liquid and solid particles floating in the air, and include sulphate, nitrate, elemental carbon, organic carbon matter, sodium and ammonium ions in varying concentrations. Of greatest concern to public health are the particles small enough to evade the body defences and thus likely to be inhaled into the deepest parts of the lung and even enter the bloodstream. Particular focus in the measurement has been thus given to particles are less than 10 microns in diameter (PM10) or less than 2.5 microns in diameter (PM2.5).

Internationally comparable measures of air quality at the local level can be derived from two main sources. The first is represented by surface-based air pollution sensors, that have been installed in several large OECD cities (generally those of more than 100000 inhabitants). The second source is constituted by estimates from satellite observation. The main shortcoming with the first source is that sensors are generally not present in developing countries, with the exception of few major cities that have been regularly monitored. This means that for the great majority of the world population we are not able to produce even rough estimates of exposure to toxic particles on the basis of ground measurement. This shortcoming does not extend to measures derived from satellite observation. The reliability of this second class of measures is however still questioned, in particular because of the difficulty to distinguish particles that are close to the ground (and can thus be inhaled by people) from those high in the atmosphere. Measurement from satellite observation is also complicated by clouds, and by bright surfaces such as snow or desert sand.

Given our main objective of developing comparable local data, we opted for the use of satellite-based measures of PM2.5 concentrations. As for ground-based measurement, it is not possible to distinguish the fraction of particulate matters originating from human activities and the fraction that is due natural sources 
(such as the winds lifting large amounts of mineral dust aloft in the Arabian and Saharan deserts). In order to provide clear indications of the health damages associated to particular levels of PM2.5 concentrations, we benchmarked the estimated levels to the thresholds specified in the WHO Air Quality Guidelines for PM.

\section{Selected indicators}

The current two indicators have been selected The indicators have been developed for OECD TL2 regions and for OECD metropolitan areas:

- $\quad$ Average population exposure to PM2.5

- $\quad$ Percentage of population exposed to health damaging PM2.5

\section{Selected results}

Table 6 shows the results of the population weighted average levels of PM2.5 for the OECD largest metropolitan areas. The highest levels of PM2.5 are observed in the metropolitan area of Milan, in part as a consequence of the naturally high levels of particulate concentration that exist throughout the Pianura Padana area. The inhabitants of San Francisco are exposed to the lowest levels of PM2.5 in this sample of large cities.

Table 6. Air pollution by PM2.5 (2001-06) - population weighted average for ten largest OECD metropolitan areas

\begin{tabular}{|c|c|c|c|}
\hline Rank & Country & Metropolitan area & $\begin{array}{c}\text { Population weighted average of } \mathrm{PM}_{2.5} \\
\text { concentration }\left[\mu \mathrm{gg} / \mathrm{m}^{3}\right]\end{array}$ \\
\hline 1 & Japan & Tokyo & 22.35 \\
\hline 2 & Korea & Seoul - Incheon & 27.10 \\
\hline 3 & Mexico & Mexico City & 25.75 \\
\hline 4 & Japan & Osaka & 21.16 \\
\hline 5 & United States & New York & 19.61 \\
\hline 6 & United States & Los Angeles & 13.35 \\
\hline 7 & France & Paris & 18.28 \\
\hline 8 & United Kingdom & London & 19.67 \\
\hline 9 & United States & Chicago & 16.37 \\
\hline 10 & United States & San Francisco & 8.07 \\
\hline
\end{tabular}

Figure 3 shows the percentage of population in each country that are exposed to different levels of air pollution, as defined by the WHO Air Quality Guidelines for PM2.5. It can be seen that a large fraction of the population of China and India breaths air whose PM2.5 concentration is worryingly high (above 35 micrograms per cubic meter, a level scientifically proved to be health-damaging). 
Figure 3. Population exposed to PM2.5 air pollution, by WHO thresholds

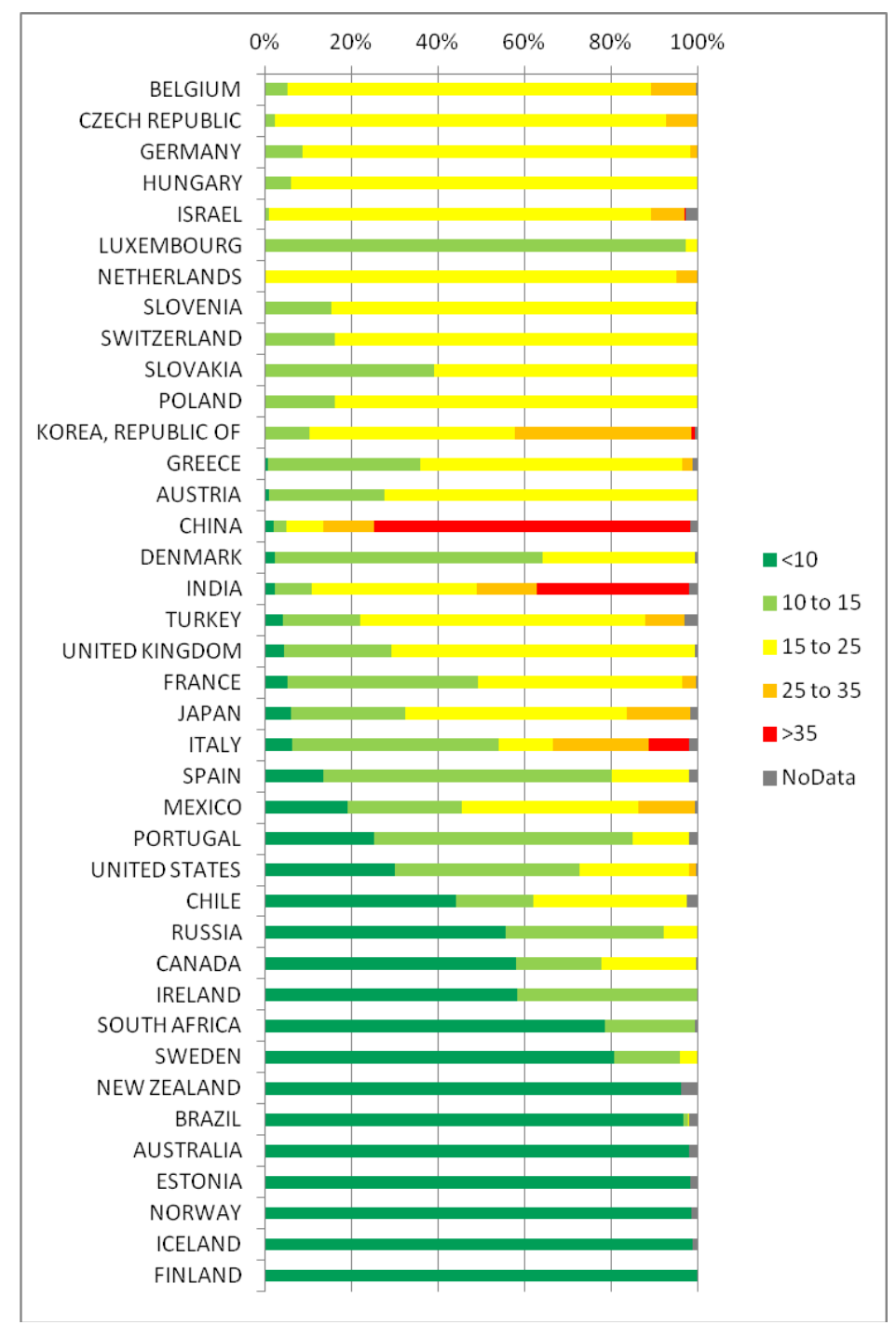

Source: OECD (2011), OECD Regions at a Glance, 2011, OECD Publishing, Paris.

\section{Remaining issues for measurement and updates}

One limitation of the described air pollution indicators is that they reflect only one type of air pollutants. Others important pollutants like PM10, ozone, nitrogen dioxide and sulfur dioxide were not taken into account due to lack of data similar to PM2.5 gridded dataset. However newly available dataset of nitrogen dioxide can be used for future work. As already said, a further limitation for interpretation and policy implications is the fact that the captured PM2.5 pollution can be of natural, artificial or combined origin.

There are also issues related to future updates of the indicators. The estimations are based on results from a very recent and advanced model. However, the data blending technique used by Van Donkelaar and colleagues is still expected to under or over-estimate the abundance of PM2.5 by $25 \%$ or more in some 
areas due to remaining uncertainties and assumptions. It is likely that even more advanced techniques for the processing of satellite observations will be developed over the next years. ${ }^{5}$

As new maps replace the ones used for the indicators, it would be advisable to replace the current estimates with new estimates based on the improved input data. Such a process would require a constant monitoring of scientific progresses in this field and a continuous investment in the refinement of the statistics. More importantly, as these high-quality estimates are often based on scientific projects in university laboratories and not on institutionalised programs, it is not sure that these data will be made available in the future and for more points in time. The policy-relevance of the results, in particular for developing countries that are rapidly urbanising, suggests the opportunity of the development of appropriate data development platforms with the explicit objective of monitoring changes.

\section{Conclusions}

This paper shows the feasibility and relevance of integrating data from geographic sources in the existing databases of regional and urban indicators. Technological improvements and rapid progresses in the acquisition and modelling of observations from satellites have greatly increased the reliability of these data. Given the level of geographic resolution at which the data are made available, it is possible to use them for the measurement of environmental state and performance of the two largest classes of metropolitan areas (as defined in OECD (2011c)).

The indicators presented in this paper are relevant for the monitoring of key environment assets of regions and urban areas, providing information on changes in land utilisation, ecosystems, carbon emissions and air quality. This information can be used together with existing indicators on economic performance, already available in the OECD Regional Dataset and under development for the new OECD Metropolitan Area Dataset. Such a data production effort should thus be seen as a step towards the construction of an integrated spatial and socio-economic dataset, that will enable better analysis of links between demographic, economic and environmental trends at the regional and urban level.

Further analysis is needed for the finalisation and validation of the indicators referring to urban density and carbon emissions. It is particularly important to better understand to what extent the indicators that have been constructed through the downscaling of national data can be used for analysis of changes. Moreover, it has been shown that the periodic update of some of the indicators can be challenging, mainly due to uncertainty regarding data availability in the future.

While representing an extremely rich and still underexploited resource for international comparisons at sub-national levels, data from geographic sources can only complement more traditional data collection instruments. A strong effort of international coordination is needed to identify and implement a strategy of harmonised data collection for urban areas. Particular investments need to be dedicated to the production of comparable data at the urban and regional level on waste management, urban transport and energy generation and use.

The final goal of the agenda to which this work contributes should be the development of a comprehensive set of interrelated indicators, in the four axes defined by the OECD for the Green Growth Strategy: $i$ ) indicators reflecting the environmental efficiency of production; $i$ ) indicators of the natural asset base; iii) indicators monitoring the environmental quality of life; iv) indicators describing policy responses and economic opportunities. The production of this information is an essential pre-condition for effective policy actions pursuing simultaneously economic growth and environmental sustainability.

5. For example, in 2012 scientists from Goddard's Institute for Space Studies (GISS) in New York will begin to analyze the first data from Glory, a satellite that carries an innovative type of instrument - a polarimeter - that will measure particle properties in new ways and complement existing instruments capable of measuring aerosols from space. 


\section{References}

Agarwal, C., G. M. Green, J. M. Grove, T. P. Evans, and C. M. Schweik (2002) A Review and Assessment of Land-Use Change Models: Dynamics of Space, Time, and Human Choice. General Technical Report NE-297. U.S. Department of Agriculture, Northeastern Research Station. 61 pp.

Campbell, N. A. (1990) Biology. Redwood City, CA, The Benjamin/Cummings Publishing Company, Inc.

Clark et al. (2001) Measuring net primary production in forests: concepts and field methods, Ecological Applications, 11(2), 2001, pp. 356-370

Corine Land Cover 2000 raster data - version 13 http://www.eea.europa.eu/data-and-maps/data/corineland-cover-2000-raster

European Commission, Joint Research Centre (JRC)/Netherlands Environmental Assessment Agency (PBL). Emission Database for Global Atmospheric Research (EDGAR), release version 4.1. http://edgar.jrc.ec.europa.eu, 2010.

European Environment Agency: Corine Land Cover 2000 - 2006 changes - version 13 http://www.eea.europa.eu/data-and-maps/data/corine-land-cover-2000-2006

Ewing, Reid (1997) “Is Los Angeles-Style Sprawl Desirable?”Journal of American Planning Association Winter 1997; v.63, n.1; pp.107-126.

Fisher,P. A. J. Comber and R. Wadsworth (2005) "Land use and Land cover: Contradiction or Complement". In P. Fisher, D. Unwin Re-Presenting GIS: 85-98, Chichester: Wiley.

Gough C.M., (2011) Terrestrial Primary Production: Fuel for Life. Nature Education Knowledge 2(2):1.

Granier C. et al (2010) Evaluation of Global and Regional Gridded Distribution of Emissions, available at http://www.epa.gov/ttnchie1/conference/ei19/session5/granier.pdf

Herold M. (2009) Assessment of the status of the development of the standards for the Terrestrial Essential Climate Variables: Land Cover, FAO, 2009

Imhoff ML, Bounoua L, (2006) "Exploring global patterns of net primary production carbon supply and demand using satellite observations and statistical data", Journal of Geophysical ResearchAtmospheres, 111 (D22): Art. No. D22S12, NOV 222006.

Kennedy, C.A et al, (2009) Greenhouse Gas Emission Baselines for Global Cities and Metropolitan Regions, available http://siteresources.worldbank.org/INTURBANDEVELOPMENT/Resources/3363871256566800920/6505269-1268260567624/KennedyComm.pdf

Lopez, R. and H. Patricia Hynes (2003) Sprawl in the 1990s: Measurement, Distribution, and Trends Urban Affairs Review 38: 325-355

Malhi Y., P. Meir1 \& S. Brown (2002) Forests, carbon and global climate Phil. Trans. R. Soc. Lond. A $360,1567-1591$

MOD17 User guide. http://www.ntsg.umt.edu/sites/ntsg.umt.edu/files/modis/MOD17UsersGuide.pdf 
MODIS GPP/NPP project MOD17. Net primary productivity, 2000-2006 annual mean. ftp.ntsg.umt.edu/pub/MODIS/Mirror/MOD17A3.305/Improved_MOD17A3_C5.1_GEOTIFF_1km

MODIS Land Cover Type (MCD12Q1) product distributed by the Land Processes Distributed Active Archive Center (LP DAAC), located at the U.S. Geological Survey (USGS) Earth Resources Observation and Science (EROS) Center (lpdaac.usgs.gov).

National Land Information Service: Mesh subdivision land use national land information data http://nlftp.mlit.go.jp/ksj/jpgis/datalist/KsjTmplt-L03-b.html

OECD (2009) The Economics of Climate Change Mitigation: Policies and Options for Global Action and beyond 2012, OECD Publishing

OECD (2010), Cities and climate change, OECD Publishing

OECD (2011), Regions at a Glance 2011, OECD Publishing

OECD (2011b) Towards Green Growth: Monitoring Progress - OECD Indicators, OECD, 2011

OECD (2011 c) Redefining urban: A new way to measure metropolitan areas in OECD countries; document presented at the $22^{\text {nd }}$ session of the WPTI. GOV/TDPC/TI(2011)3

U.S. Geological Survey: National Land Cover Database 2001/2006 Land Cover Change http://www.mrlc.gov/nlcd_2006.php

Van Donkelaar, A., R. V. Martin, M. Brauer, R. Kahn, R. Levy, C. Verduzco, and P. J. Villeneuve (2010) Global Estimates of Exposure to Fine Particulate Matter Concentrations from Satellite-based Aerosol Optical Depth, Environ. Health Perspec., 118(6), http://fizz.phys.dal.ca/ atmos/g47.swf

WHO (2006) Air Quality Guidelines. Global update 2005. World Health Organization 2006. http://www.euro.who.int/Document/E90038.pdf

Zhao, M. and Running, S. W. (2010) Drought-Induced Reduction in Global Terrestrial Net Primary Production from 2000 Through 2009. Science 20 August 2010: Vol. 329 no. 5994 pp. 940-943. 


\section{ANNEX: DATA SOURCES AND DATA PROCESSING}

\section{Land Cover}

\section{Data sources}

Data availability was a major issue when assessing land cover changes at global level. Despite recent progress in earth observation, remote sensing and techniques for processing large datasets, there is still no globally comparable dataset recording land cover change. Present global land cover datasets (e.g. MODIS Land Cover) are limited to static measures of land cover composition. They are aimed primarily at regional to global scale monitoring and have relatively rough resolution (down to $0.5 \mathrm{~km}$ cell size). Therefore, it was necessary to use multiple sub-global land cover change datasets where available.

In European countries the CORINE (Coordination of information on the environment) programme has been running since 1985 thanks to collaboration between the European Commission and national teams, supported also by the European Environmental Agency and the European Space Agency. One of its projects, CORINE Land Cover (CLC), resulted in a series of products capturing the state of European land cover and its recent changes (including the period 2000-06). In the United States, the Multi-Resolution Land Characterisation Consortium, composed of 11 federal agencies (NASA, USGS and NOAA among others), has produced the National Land Cover Database (NLCD), which includes identification of changes for the period 2001-06. In Japan, as a part of Japan National Land Information Service (JNLIS), a series of gridded datasets was published for the whole territory of Japan. It includes comparable information for the years 1997 and 2006.

The three land cover change datasets mentioned above differ substantially in multiple aspects classification systems, definitions of land cover classes, methodology of production, spatial resolution, minimum mapping unit etc. The difference in classification was reduced by the merging of groups of classes into a lower number of more general land cover classes. Notwithstanding this harmonisation, the comparability between the three products still presents issues due to differences that could not be reduced. This should be kept in mind when using the information.

The reclassification of the three datasets into a common more general scheme was a major task since there is no way of doing it that would be utterly correct. For instance, the group of classes 241 to 244 in CLC are termed "heterogeneous agricultural areas" which means that the areas of this class contain mix of multiple land cover types but the patches are smaller than the minimum mapping unit of 25 hectares and therefore they cannot be captured as separate classes. Instead they are classified as heterogeneous areas (e.g. land principally occupied by agriculture, with significant areas of natural vegetation). These classes do not have a counterpart in the United States and Japan, because these two datasets have significantly smaller mapping unit, so that each of the small patches could be identified as a specific homogeneous class. 
The final classification used to calculate the statistics for regions consists of six classes (see table 6 for comparison of reclassification schemes and other information on the three employed datasets):

1. Water (lakes, river, lagoons etc.)

2. Agriculture (annual crops, rice fields, orchards, pastures etc.)

3. Forest (coniferous, broad-leaved, mixed etc.)

4. Non-forest natural vegetation (natural grasslands, shrublands, sparsely vegetated areas etc.)

5. Urban (residential, industrial, major transportation, green urban areas etc.)

6. Other (bare lands, wetlands, glaciers)

\section{Data processing}

\begin{tabular}{|l|}
\hline \multicolumn{1}{c|}{ Steps for land cover } \\
\hline $\begin{array}{l}\text { First, origin and destination land cover rasters were needed to be created for further analysis. CLC 2000, NLCD } \\
2001 \mathrm{v} 2.0 \text { and JNLIS } 1997 \text { datasets were used as origin rasters. CLC and NLCD destination raster were created using } \\
\text { special change products (containing only cells that have changed their class). The new values of the changed cells } \\
\text { were kept and the remaining cells were added from the origin rasters. A change product was not available from JNLIS } \\
\text { therefore the } 2006 \text { raster was used in its original form }\end{array}$ \\
\hline $\begin{array}{l}\text { All six rasters were reclassified into the generalised } 6 \text {-class scheme (see above) using Reclassify tool in Spatial } \\
\text { Analyst }\end{array}$ \\
$\begin{array}{l}\text { Reclassified origin and destination rasters were combined using Combine tool in Spatial Analyst, so that each cell } \\
\text { contained one of the } 36 \text { possible combined from-to values (1-1, } 1-2,1-3 \text { up to } 6-6)\end{array}$ \\
\hline $\begin{array}{l}\text { Raster representation of the studied regions was created for each of the datasets with corresponding coordinate } \\
\text { system and cell size (Polygon to raster in Conversion Tools) }\end{array}$ \\
\hline $\begin{array}{l}\text { Tabulate area tool in Spatial Analyst was then used to calculate a matrix of the areas of each of the from-to classes in } \\
\text { each of the regions in a single step; this has to be done separately for each of the three datasets }\end{array}$ \\
$\begin{array}{l}\text { By summing up specific groups of classes in the output matrix it is possible to generate any of the desired static or } \\
\text { dynamic indicators, e.g. summing of the classes } 1-5,2-5,3-5,4-5,5-5,6-5 \text { will result in the total area of urban land in } \\
\text { year } 2006 ; \text { summing of the classes } 3-1,3-2,3-4,3-5,3-6 \text { will result in forest consumption (the area of land that was } \\
\text { converted from forest to other types of land cover during the studied period) }\end{array}$ \\
\hline
\end{tabular}

For regions in other countries than the EU, US and Japan, the MODIS Land Cover product was used to estimate the proportion of urban (class 13 in IGBP classification) and forest land (classes 1- 5 in IGBP classification). The MODIS Land Cover is released each year and 2008 data were used for estimation. The urban class refers to 2001-02 MODIS data, as updated estimates of urban land are still not available for later years. 
Table 7. Comparison of employed land cover products

\begin{tabular}{|c|c|c|c|}
\hline Aspect & EU CORINE Land Cover & $\begin{array}{l}\text { US National Land Cover } \\
\text { Database }\end{array}$ & $\begin{array}{c}\text { Japan National Land Information } \\
\text { Service }\end{array}$ \\
\hline Years & 2000,2006 & 2001,2006 & 1997,2006 \\
\hline Cell size & $100 \mathrm{~m}$ & $30 \mathrm{~m}$ & 3 by 4 arc-sec (ca. 100 by $100 \mathrm{~m})$ \\
\hline Min. mapping unit & $\begin{array}{l}25 \text { cells ( } 5 \text { cells for identification } \\
\text { of change) }\end{array}$ & 5 cells & 1 cell \\
\hline Number of classes & 44 & 16 & 11 \\
\hline Source data & $\begin{array}{l}\text { Landsat Enhanced Thematic } \\
\text { Mapper+ Imagery (2000); } \\
\text { SPOT4, SPOT5, IRS-P6 } \\
\text { Imagery (2006) }\end{array}$ & $\begin{array}{l}\text { Landsat Enhanced } \\
\text { Thematic Mapper+ } \\
\text { Imagery }\end{array}$ & $\begin{array}{l}\text { Topographic maps, existing land } \\
\text { use maps, satellite imagery }\end{array}$ \\
\hline $\begin{array}{l}\text { Generalised } \\
\text { 6-class scheme }\end{array}$ & \multicolumn{3}{|c|}{ Groupings of original classes } \\
\hline $\begin{array}{l}\text { 1. Water } \\
\text { (lakes, rivers, } \\
\text { lagoons etc.) }\end{array}$ & $\begin{array}{l}\text { 511. Water courses } \\
\text { 512. Water bodies } \\
\text { 521. Coastal lagoons } \\
\text { 522. Estuaries } \\
\text { 523. Sea and ocean }\end{array}$ & 11. Open Water & $\begin{array}{l}\text { B. Rivers and lakes - Lakes } \\
\text { (natural and manmade), ponds } \\
\text { and fish cultivation that normally } \\
\text { have water; rivers and river banks } \\
\text { F. Sea water - Rocks on and off } \\
\text { water, tideland, sea berths are } \\
\text { included }\end{array}$ \\
\hline $\begin{array}{l}\text { 2. Agriculture } \\
\text { (annual crops, rice } \\
\text { fields, orchards, } \\
\text { pastures etc.) }\end{array}$ & $\begin{array}{l}\text { 211. Non-irrigated arable land } \\
\text { 212. Permanently irrigated land } \\
\text { 213. Rice fields } \\
\text { 221. Vineyards } \\
\text { 222. Fruit trees and berry } \\
\text { plantations } \\
\text { 223. Olive groves } \\
\text { 231. Pastures } \\
\text { 241. Annual crops associated } \\
\text { with permanent crops } \\
\text { 242. Complex cultivation } \\
\text { patterns } \\
\text { 243. Land principally occupied } \\
\text { by agriculture, with significant } \\
\text { areas of natural vegetation } \\
\text { 244. Agro-forestry areas }\end{array}$ & $\begin{array}{l}\text { 81. Pasture/Hay } \\
\text { 82. Cultivated Crops }\end{array}$ & $\begin{array}{l}\text { 1. Field - Field for rice (wet and } \\
\text { dry) and field for lotus. } \\
\text { 2. Other agricultural land - Land } \\
\text { for wheat, vegetables, grass, } \\
\text { apples, pears, peaches, grapes, } \\
\text { tea leaves, etc. }\end{array}$ \\
\hline $\begin{array}{l}\text { 3. Forest } \\
\text { (coniferous, broad- } \\
\text { leaved, mixed etc.) }\end{array}$ & $\begin{array}{l}\text { 311. Broad-leaved forest } \\
\text { 312. Coniferous forest } \\
\text { 313. Mixed forest }\end{array}$ & $\begin{array}{l}\text { 41. Deciduous Forest } \\
\text { 42. Evergreen Forest } \\
\text { 43. Mixed Forest }\end{array}$ & $\begin{array}{l}\text { 5. Forests - Perennial plants } \\
\text { densely vegetated. }\end{array}$ \\
\hline $\begin{array}{l}\text { 4. Other (non-forest) } \\
\text { natural vegetation }\end{array}$ & $\begin{array}{l}\text { 321. Natural grasslands } \\
\text { 322. Moors and heathland } \\
\text { 323. Sclerophyllous vegetation } \\
\text { 324. Transitional woodland- } \\
\text { shrub } \\
\text { 333. Sparsely vegetated areas } \\
\text { 334. Burnt areas }\end{array}$ & $\begin{array}{l}\text { 52. Shrub/Scrub } \\
\text { 71. Grassland/Herbaceous }\end{array}$ & G. Golfcourse \\
\hline $\begin{array}{l}\text { 5. Urban } \\
\text { (residential, } \\
\text { industrial, major } \\
\text { transportation, green } \\
\text { urban areas etc.) }\end{array}$ & $\begin{array}{l}\text { 111. Continuous urban fabric } \\
\text { 112. Discontinuous urban fabric } \\
\text { 121. Industrial or commercial } \\
\text { units } \\
\text { 122. Road and rail networks and } \\
\text { associated land } \\
\text { 123. Port areas } \\
\text { 124. Airports } \\
\text { 141. Green urban areas } \\
\text { 142. Sport and leisure facilities }\end{array}$ & $\begin{array}{l}\text { 21. Developed, Open Space } \\
\text { 22. Developed, Low } \\
\text { Intensity } \\
\text { 23. Developed, Medium } \\
\text { Intensity } \\
\text { 24. Developed, High } \\
\text { Intensity }\end{array}$ & $\begin{array}{l}\text { 7. Land for buildings - Residential } \\
\text { areas and built-up areas where } \\
\text { buildings are densely located } \\
\text { 9. Land for major transportation - } \\
\text { Roads, railways and stations that } \\
\text { could be perceived as areas. } \\
\text { A. others - Stadiums (horserace, } \\
\text { baseball and other sports), } \\
\text { airports, school grounds, artificial } \\
\text { vacant land }\end{array}$ \\
\hline
\end{tabular}




\begin{tabular}{|c|c|c|c|}
\hline Aspect & EU CORINE Land Cover & $\begin{array}{c}\text { US National Land Cover } \\
\text { Database }\end{array}$ & $\begin{array}{c}\text { Japan National Land Information } \\
\text { Service }\end{array}$ \\
\hline $\begin{array}{l}\text { 6. Other } \\
\text { (bare lands, } \\
\text { wetlands, glaciers) }\end{array}$ & $\begin{array}{l}\text { 131. Mineral extraction sites } \\
\text { 132. Dump sites } \\
\text { 133. Construction sites } \\
\text { 331. Beaches, dunes, sands } \\
\text { 332. Bare rocks } \\
\text { 335. Glaciers and perpetual } \\
\text { snow } \\
\text { 411. Inland marshes } \\
\text { 412. Peat bogs } \\
\text { 421. Salt marshes } \\
\text { 422. Salines } \\
\text { 423. Intertidal flats }\end{array}$ & $\begin{array}{l}\text { 12. Perennial Ice/Snow } \\
\text { 31. Barren Land } \\
\text { 90. Woody Wetlands } \\
\text { 95. Emergent Herbaceous } \\
\text { Wetlands }\end{array}$ & $\begin{array}{l}\text { 6. Bare land - Bare land, cliffs, } \\
\text { land covered by snow, wetlands, } \\
\text { land for mining } \\
\text { E. Coastal Land - Sands and } \\
\text { rocks adjacent to coasts }\end{array}$ \\
\hline
\end{tabular}

\section{Forest ecosystem and carbon absorption}

\section{Data sources}

The data are derived from MOD17, one of the projects exploiting satellite data from the MODIS mission. MOD17 aims at estimating the geographic distribution of global gross and net primary productivity of vegetation on the Earth's surface. Global productivity can be estimated by combining remote sensing with carbon cycle processing. The variable of interest here is the net amount of carbon that is absorbed by plants per year per unit of area on average in a given region. For this purpose we employed NPP global raster dataset representing 2000-06 annual mean with cell size of 30 arc seconds (about 600 by 900 meters in mid-latitudes). ${ }^{6}$

\section{Data processing}

Data processing tasks were carried out using ArcGIS Desktop 9.3. The following sequence of steps was taken to obtain the results.

\section{Steps for natural vegetation and carbon absorption}

The source raster dataset representing NPP 2000-2006 annual average was reclassified - NoData cells were converted to value 0 in order to be included in the analysis (NoData cells were found e.g. in urbanised areas)

The unit of measurement of the NPP variable is grams of carbon per meter squared per year. In order to calculate regional average it has to be taken into account that the actual area of each raster cell is variable, therefore an areaweighted average of the cells has to be calculated

The NPP input raster was multiplied by an areagrid representing area of each 30 by 30 arc-second cell in $\mathrm{m}^{2}$ using Raster calculator in Spatial Analyst

Two series of zonal sums were calculated for studied regions using the multiplied raster and using the areagrid (Zonal statistics in Spatial Analyst)

Ratio of the two zonal sums was calculated for each region to obtain the area-weighted NPP average

6. The basic idea behind the creation of this data product was that in optimal conditions of moisture and fertility the NPP is linearly related to the amount of absorbed photosynthetically active solar radiation, which depends upon the geographic and seasonal variability of daylength and potential incident radiation, and the amount and geometry of displayed leaf material. This relation is further modified by variability of suboptimal climatic conditions (like drought and low temperatures) and intensity of plant respiration. 


\section{Urban density}

\section{Data sources}

For the calculation of the densification index two types of data are needed. Change of population is identified using census data. Change of urban land is identified using land cover data. For more information see section three.

To calculate the high density development index, we needed gridded population data with a good coverage of OECD countries and relatively high spatial resolution. LandScan 2009 Global Population dataset, developed by Oak Ridge National Laboratory (ORNL) satisfied these requirements and therefore was chosen. Its cell size is 30 by 30 arc-seconds, which corresponds to ca 600 by 900 meters in midlatitudes.

\section{Data processing}

Data processing tasks were carried out using ArcGIS Desktop 9.3. The following sequence of steps was taken to obtain the results.

\section{Steps for urban density}

A raster representation of analyzed metropolitan areas was created (Conversion tools - polygon to raster). A maximum combined area method was used as well as cell size and coordinate system identical with LandScan population dataset

A raster with metropolitan areas was used to extract a separate raster files representing each of the metro regions from the LandScan dataset (Extract by mask in Spatial analyst extension)

Extracted rasters were converted to point feature class (Raster to point in conversion tools), so that the raster cells could be handled as an individual entity

The attribute table of the created feature class was exported and opened in a spreadsheet processor where further steps were taken to exclude the highest and lowest $5 \%$ and calculate the index as a ratio of low and high density cells, where median is chosen as threshold between high and low density.

\section{Carbon Emissions}

\section{Data sources}

Generally, emission data are available at country level from the Intergovernmental Panel on Climate Change (IPCC). To facilitate estimation of the emission levels for geographic areas like OECD TL2 regions or metropolitan areas, the EDGAR global emission database has been used. The database is being developed by Joint Research Centre of the European Commission. EDGAR database version 4.1 provides country emission levels separately by each compound and sector of origin (e.g. $\mathrm{CO}_{2}$ emission from fuel production) geographicly allocated (disaggregated) to gridded maps on the basis of spatial data such as location of energy and manufacturing facilities, road networks, shipping routes, human and animal population density and agricultural land use. The spatial resolution of the grid is 0.1 by 0.1 degrees (the actual size of the grid cells decreases from equator to poles, in mid-latitudes it is around 7 by 11 kilometres). The gridded estimates are currently available for 2000, 2001, 2002, 2003, 2004, 2005. 
Table 8. Employed EDGAR datasets for $\mathrm{CO} 2$ estimation and included sources of emissions

\begin{tabular}{|c|c|}
\hline $\begin{array}{c}\text { Dataset name } \\
\text { (IPCC sector code) }\end{array}$ & Included sources of emissions \\
\hline Energy (1A1) & 1A1a Public electricity and heat production; 1A1bc Other energy industries \\
\hline $\begin{array}{l}\text { Industry combustion } \\
\text { and process } \\
\text { emissions }(1 \mathrm{~A} 2+2)\end{array}$ & $\begin{array}{l}\text { 1A2 Manufacturing industries and construction; 2A Production of minerals; 2B } \\
\text { Production of chemicals; 2C Production of metals; 2D Production of } \\
\text { pulp/paper/food/drink; 2E Production of halocarbons and SF6; 2F1 Refrigeration and air } \\
\text { conditioning; 2F2 Foam blowing; 2F3 Fire extinguishers; 2F4 Aerosols; 2F5 F-gas as } \\
\text { solvent; 2F7 Semiconductor/electronics manufacture } \\
\text { 2F8 Electrical equipment; 2F9 Other F-gas use; 2G Non-energy use of lubricants/waxes } \\
\text { (CO2) }\end{array}$ \\
\hline Air transport (1A3a) & 1A3a Domestic aviation \\
\hline $\begin{array}{l}\text { Ground transport } \\
(1 \mathrm{~A} 3,1 \mathrm{~A} 3 \mathrm{c}, 1 \mathrm{~A} 3 \mathrm{e})\end{array}$ & 1A3b Road transportation; 1A3c Rail transportation; 1A3e Other transportation \\
\hline $\begin{array}{l}\text { Inland waterways } \\
(1 \mathrm{~A} 3 \mathrm{~d} 2)\end{array}$ & 1A3d Domestic navigation \\
\hline Fuel production (1B) & 1B1 Fugitive emissions from solid fuels; 1B2 Fugitive emissions from oil and gas \\
\hline $\begin{array}{l}\text { Residential and other } \\
\text { combustion (1A4, } \\
\text { 1A5) }\end{array}$ & 1A4 Residential and other sectors \\
\hline Solvents (3) & 3 Solvent and other product use \\
\hline $\begin{array}{l}\text { Agriculture (4 excl. } \\
4 \mathrm{E})\end{array}$ & $\begin{array}{l}\text { 4A Enteric fermentation; 4B Manure management; 4C Rice cultivation; 4D1 Direct soil } \\
\text { emissions } \\
\text { 4D2 Manure in pasture/range/paddock; 4D4 Other direct soil emissions; 4F Agricultural } \\
\text { waste burning }\end{array}$ \\
\hline Solid waste $(6 A+6 C)$ & 6A Solid waste disposal on land; 6C Waste incineration \\
\hline Other sources $(7)$ & 7A Fossil fuel fires; 7D Other anthropogenic sources \\
\hline
\end{tabular}

Note: datasets representing international aviation and navigation were not included in the analysis.

\section{Data processing}

The methodology employed essentially sums the EDGAR estimated values for the 0.1 by 0.1 degrees grids over the relevant regional or metropolitan area. The data processing tasks were carried out using ArcGIS Desktop 9.3. The following sequence of steps was taken to obtain the results.

\begin{tabular}{|l|}
\hline \multicolumn{1}{|c|}{ Steps for carbon emissions } \\
\hline Input datasets were converted from NetCDF format into GIS-friendly raster format \\
\hline $\begin{array}{l}\text { All the partial datasets on single sources of emissions were summed into a single raster representing total level of CO2 } \\
\text { emission from all available sectors (using Raster Calculator in Spatial Analyst extension) }\end{array}$ \\
\hline $\begin{array}{l}\text { To derive CO2 levels for two points in time, the total rasters for years 2000-2002 and 2003-2005 were averaged to } \\
\text { smooth out potential extreme values that might occur in the yearly data }\end{array}$ \\
\hline $\begin{array}{l}\text { To aggregate raster cells values intersected by each of analyzed regions a raster representation of the regions had to } \\
\text { be created with the same coordinate system (WGS } 1984 \text { ) and cell size as the CO2 dataset. Because in the case of } \\
\text { EDGAR data the cells are relatively large, it was decided that the source raster would be resampled to } 5 \text { times finer } \\
\text { resolution }\left(0.02^{\circ} \text { ) assuming that the emission distribution inside the large cells is homogeneous. This was done simply }\right. \\
\text { by dividing the values of the resampled raster by 25. The goal of the operation was to represent the shape of the } \\
\text { region more closely (see figure 4) and to account for those large CO2 cells that are not completely within the region but } \\
\text { are intersected by the region's border. }\end{array}$ \\
\hline $\begin{array}{l}\text { Finally, Zonal Statistics tool (Spatial Analyst extension) was used to aggregate CO2 values in each of the analyzed } \\
\text { regions }\end{array}$ \\
\hline
\end{tabular}



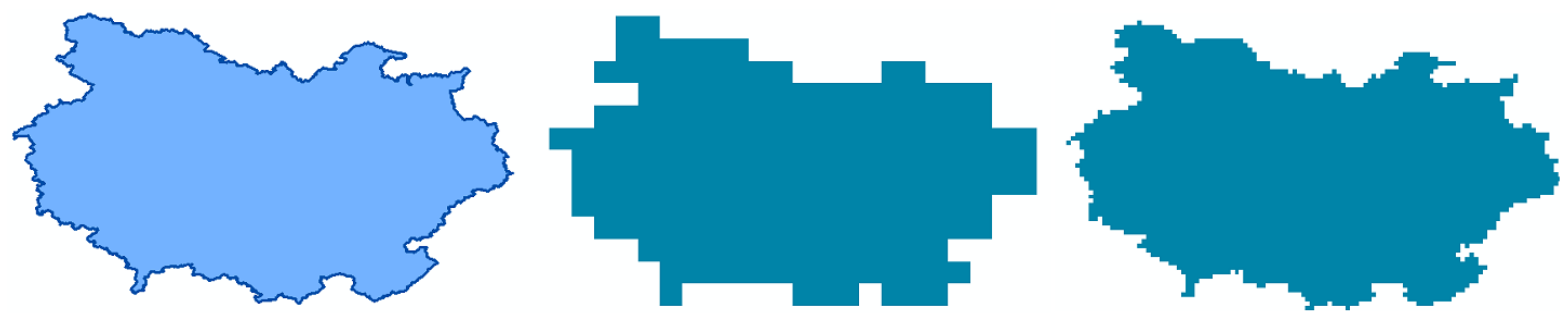

\section{Air quality}

\section{Data sources}

Similarly to the $\mathrm{CO}_{2}$ indicators, a global geo-referenced raster dataset with cell size of $0.1^{\circ}$ by $0.1^{\circ}$ was used to estimate air pollution by health-threatening fine particulate matter known as PM2.5 (particles smaller than 2.5 micrometers in diameter, of both artificial and natural origin). However, unlike the EDGAR database used for $\mathrm{CO}_{2}$ estimation, the employed PM2.5 dataset does not show the spatial distribution of the variable on the basis of disaggregation but on the basis of satellite observations of aerosol optical depth. The global mapping of PM2.5 has been developed mainly by Aaron van Donkelaar and Randall Martin from Department of Physics and Atmospheric Science, Dalhousie University, Halifax, Nova Scotia, Canada. Their approach combined satellite data from NASA's MODIS and MISR instruments and GEOS-Chem global chemical transport model. The dataset represents averages for 6 year (2001 to 2006) of PM2.5 concentration measured at 50\% relative humidity, a standard in agreement with European standards for ground-based measurements.

Because long-term exposure to airborne PM2.5 is associated with negative human health impacts, not the pollution as such but the degree of human exposure to it was the prime concern. For instance, there are large areas with naturally high levels of PM2.5 (e.g. Sahara desert) that are almost uninhabited, thus the impact on such pollution on population is low. To take into account the impact on population, the number of people in the area covered by each of the pollution cells was estimated. LandScan Global Population dataset, a gridded representation of population with 12 times finer resolution compared to the pollution raster was well-suited for this task (see Figure 5).

Two types of indicators were created. The first is the share of population living in areas exceeding certain WHO pollution threshold (see Table 6). The second indicator is a population-weighted average of PM2.5 cell values. It can be interpreted as the concentration of PM2.5 particles to which people are exposed on average in a region.

Table 9. WHO Air Quality Guidelines and Interim Targets for annual mean of PM2.5 concentrations

\begin{tabular}{|l|l|l|}
\hline \multicolumn{1}{|c|}{ Title } & \multicolumn{1}{|c|}{$\begin{array}{c}\text { PM2.5 } \\
(\mu \mathrm{g} / \mathrm{m} 3)\end{array}$} & \multicolumn{1}{c|}{ Description } \\
\hline $\begin{array}{l}\text { Interim target-1 (IT- } \\
\text { 1) }\end{array}$ & 35 & $\begin{array}{l}\text { These levels are associated with about a 15\% higher long-term mortality } \\
\text { risk relative to the AQG level }\end{array}$ \\
\hline $\begin{array}{l}\text { Interim target-2 (IT- } \\
2)\end{array}$ & 25 & $\begin{array}{l}\text { In addition to other health benefits, these levels lower the risk of } \\
\text { premature } \\
\text { mortality by approximately 6\% (2-11\%) relative to the IT-1 level }\end{array}$ \\
\hline $\begin{array}{l}\text { Interim target-3 (IT- } \\
\text { 3) }\end{array}$ & 15 & $\begin{array}{l}\text { In addition to other health benefits, these levels reduce the mortality risk } \\
\text { by approximately 6\% (2-11\%) relative to the IT-2 level }\end{array}$ \\
\hline $\begin{array}{l}\text { Air Quality } \\
\text { Guideline (AQG) }\end{array}$ & 10 & $\begin{array}{l}\text { These are the lowest levels at which total, cardiopulmonary, and lung } \\
\text { cancer mortality have been shown to increase with more than 95\% } \\
\text { confidence in response to long-term exposure to PM2.5 }\end{array}$ \\
\hline
\end{tabular}




\section{Data processing}

The data processing tasks were carried out using ArcGIS Desktop 9.3. The following sequence of steps was taken to obtain the population weighted average of PM2.5 concentration.

\section{Steps for population weighted average of PM2.5 concentration}

The PM2.5 pollution raster and LandScan population raster were combined by multiplying their cell values using Raster Calculator in Spatial Analyst extension, with target resolution of the finer raster (30" arc seconds i.e. ca $1 \mathrm{~km})$

Studied regions were converted from vector polygons to raster (Polygon to raster in Conversion toolbox) using maximum combined area method and target resolution of the input population raster

Zonal statistics in Spatial analyst were used to calculate zonal sums for each of the regions using the multiplied pollution-population raster

Zonal statistics in Spatial analyst were used to calculate zonal sums for each of the regions using the population raster itself

The population weighted average pollution level was calculated as a ratio of the previously obtained zonal sums

Figure 5. An example of PM2.5 and population grid cells overlay

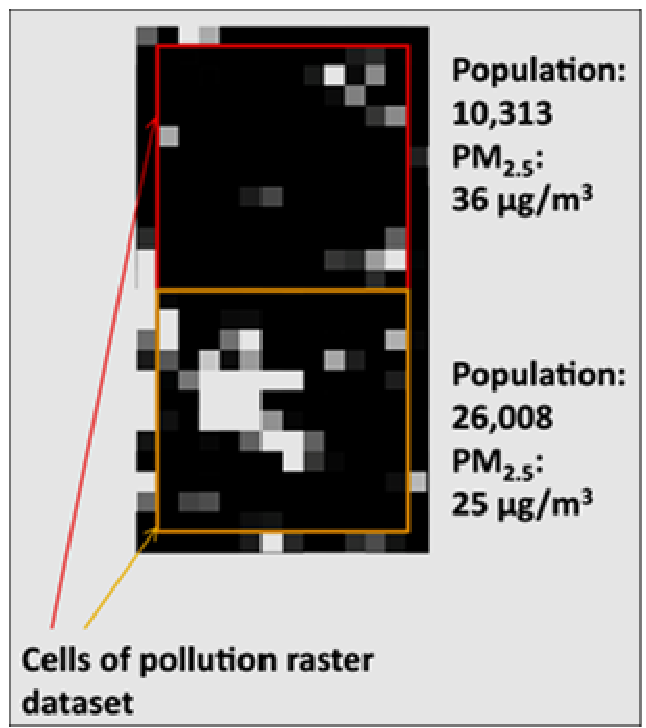

The following sequence of steps was taken to obtain the composition of population with respect to WHO PM2.5 concentration guidelines:

Steps for average population with respect to WHO PM2.5 concentration

The pollution raster was reclassified into 6 classes using the WHO guidelines (below 10, 10-15, 15-25, 25-35 and over $35 \mu \mathrm{g} / \mathrm{m} 3$ ) using Reclassify tool in Spatial analyst

Reclassified raster was combined with the raster representation of studied regions using Combine tool in Spatial analyst so a unique zone for each combination of region and pollution class was created

Zonal sums of population were calculated for each of the combined zones using the LandScan population raster (Zonal Statistics in Spatial Analyst) 